\title{
SOME RETROSPECTIVE MUSINGS
}

\author{
Noel P. Gist \\ University of Missouri
}

My professional and personal association with Carroll Clark began in the Fall of 1930 when he rejoined the staff of the University of Kansas after a period of graduate studies at the University of Chicago. The departmental staff was immensely pleased to have Carroll return, and it was especially gratifying to know that he would take the helm as chairman because his reputation as a scholar and teacher was already well established.

The staff during those years was small; among the senior members were Frank Blackmar, Victor Helleberg, Seba Eldridge, and Stuart Queen, who resigned the chairmanship in 1930 to take a position elsewhere. Like many departments in those days the staff and graduate students comprised an intimate primary group. It was thus possible to interact on an informal basis, and to conduct our professional roles and relationships more or less informally. The interaction, though informal, was not always harmonious, however. Feuds in a small department are almost always disruptive, and this situation was no exception.

But Carroll had precisely the personal qualities needed at this juncture. He was liked and respected by everyone. He was above petty bickering. He refused to become involved in any intra-departmental conflict. I recall very vividly a statement he made at the first staff meeting, after his appointment, that as chairman he would sanction no collusive discrimination against any of his colleagues. It was this philosophy of fairness, always confirmed by his actions as chairman, that provided a stabilizing and unifying influence in a departmental situation that might otherwise have been demoralizing. This conception of fair play brought him, through the years, the undivided support and cooperation of his departmental colleagues. Although I resigned to take another position in 1937, I have always been keenly aware of the admiration and affection his colleagues have held for him - feelings that I fully share.

Carroll has never published very extensively, but what he did write was first rate, often important. Like his guide and mentor, Professor Robert E. Park, his intellectual contributions were more often made in 
the classroom or in his consultations with students or colleagues than on the printed page. I well recall the remark he made to me when he was preparing a paper to be read at one of the professional meetings. For weeks he had been working hard to organize his thinking on the subject. Said Carroll, "My audience, when I read this paper, will be Robert E. Park; I don't particularly care what others think of it." The title of the paper was "The Concept of the Public." A major contribution to the field of scholarly works, it has been reprinted in a number of publications.

Carroll joined me in a study of selective aspects of migration and occupational choice in Kansas during the 1930s. The study involved considerable field work in gathering relevant data in rural communities scattered widely over the state. Obviously, certain expenses were involved in the operation. But this was a depression decade and there was little money available for research - and for salaries either, for that matter. After a solicitous request for money from the appropriate university committee we were "generously" awarded a grant of fifty dollars to carry out research. A student on the "works" program at the time was employed to do the interviewing. I contributed the use of my old car to enable the interviewer to gather data in about a hundred communities. There being no computers in those days, we did all the sorting of data by hand.

Thus Carroll and I worked together on the proverbial shoestring to carry out a piece of research which, in these days of affluence, would involve a financial layout many times larger. Perhaps we were encouraged by the remark that our colleague, Seba Eldridge, often made about research expenditures; it was to the effect that the quality of scholarly work may well be inversely related to the amount of money spent in carrying it out. The aspect of the collaborative effort that was especially gratifying, at least to me, was the genuine spirit of cooperation manifest by Carroll, and the valuable ideas he contributed in the analysis of the data. His incisive intellectual powers were tempered by his gentle wit and his innate modesty - qualities which have always endeared him to his friends and associates.

It is difficult to determine what role an individual is best qualified to follow, or in what role an individual can make his greatest contribution to society. Because I was always aware of Carroll's superb intellectua powers and his great potentialities as a research scholar I rather regretted that he was burdened with the departmental chairmanship so long - some three decades. But if the profession of Sociology was deprived of important contributions that Carroll might have made if he had been relieved of the arduous duties of a chairman, it may be that his contributions, of a rather different character, were equally important.

In many ways he does exemplify the complete academic scholar: he has always been a stimulating and creative teacher; he did build a strong department of Sociology and Anthropology, one of the best among the state universities of the Middle West; his publications are notable contributions to the profession; and his professional leadership is widely recognized. Well, what more can a man accomplish!

And so, on the year of his retirement, we join in saluting him as a beloved friend and former colleague. 